\title{
KONTRIBUSI MUI DALAM REKONFIGURASI SYARIAH DI INDONESIA
}

(Melacak Peran MUI dalam Birokratisasi Syariah di Indonesia)

\author{
Moch. Nurcholis \\ Institut Agama Islam Bani Fattah Jombang, Indonesia \\ moch.nurcholis@,iaibafa.ac.id
}

\begin{abstract}
This research describes the contribution of MUI in the reconfiguration of sharia in Indonesia, from being an unwritten law to a binding law.

MUI's efforts in reconfiguring sharia are carried out through the bureaucratization of sharia, namely the process of incorporation of sharia into national law which at an empirical level has been lived and carried out by the Muslim community in Indonesia. In contrast to the process of shariatisation or law Islamization which presupposes the replacement of national law with religious law, sharia bureaucratization is the work of labeling sharia law in legislation as an effort to guarantee legal certainty, administrative order, and achieve justice in legal disputes. The significance of the MUI's contribution in the effort to reconfigure Islamic law is evidenced by the issuance of statutory regulations sourced from fatwa products. Reconfiguration efforts are carried out in three ways, namely; First, to provide support for the birth of certain laws and regulations; Second, provide critical support and correction to a statutory regulation; Third, give a sharia fatwa.
\end{abstract}

Keywords: MUI, Reconfiguration, Bureaucratization, Islamic-Sharia Law

Tafaqquh: Jurnal Penelitian dan kajian keislaman

Volume 8, Nomor 2, Desember 2020 ; p-ISSN 2338-3186; e-ISSN 2549-1873; 179-196 


\section{Pendahuluan}

Rekonfigurasi syariah (hukum Islam) di Indonesia yang semula berwujud hukum tidak tertulis -yang telah berlaku dan tetap hidup di tengah-tengah masyarakat berdampingan dengan hukum adat dan kearifan lokal- ${ }^{1}$ menjadi hukum tertulis, oleh sebagian sarjana dianggap sebagai bentuk Islamisasi, Syariatisasi hukum positif di Indonesia atau hukum negara. Asep Saepudin, dalam catatannya mengemukakan bahwa anggapan yang demikian itu tidaklah benar. Ia menjelaskan bahwa terma yang tepat dalam menggambarkan fenoma masuknya hukum syariah (inkorporasi) dalam hukum nasional atau hukum negara adalah birokratisasi syariah dari akibat dari penguatan birokratisasi syariah itu sendiri. $^{2}$

Asep berpandangan bahwa fenomena birokratisasi hukum syariah di Indonesia merupakan kerja labelisasi hukum syariah dalam perundangundangan sebagai upaya menjamin kepastian hukum, ketertiban administrasi, dan untuk mewujudkan keadilan dalam sengketa hukum yang berkaitan dengan umat Islam di Indonesia sebagai masyarakat mayoritas. Hal mana juga telah dipraktikkan sejak era penjajahan. ${ }^{3}$

Penguatan birokratisasi syariah ke dalam hukum Negara dalam konteks hukum positif di Indonesia tentu tidak dapat dilepaskan sepenuhnya dari peran Majelis Ulama Indonesia (MUI). Meski secara umum produk fatwa MUI belum memiliki otoritas dan daya paksa dalam tataran pelaksanaannya, sebab produk fatwa tersebut belum terkategori sebagai sebuah aturan perundang-undangan, namun MUI telah berdaya dalam memberikan usulan draft Rancangan Undang-Undang (RUU) dan draft Peraturan Pemerintah (PP) yang pada akhirnya dapat merekonfigurasi hukum syariah yang semula masih bersifat hukum tidak tertulis menjadi hukum tertulis berwujud aturan perundangan-undangan, ${ }^{4}$ disamping tentunya telah banyak produk fatwa otoritatif yang terbit dan telah dijadikan acuan dan pedoman bagi masyarakat muslim dalam menyikapi problematika hukum kekinian. ${ }^{5}$

1 Erlina Maria Cristin Sinaga, "Politik Legislasi Hukum Tidak Tertulis Dalam Pembangunan Hukum Nasional," Jurnal RechtsVinding, Vol. 8, No. 1 (April 2019), 2.

2 Asep Saepudin Jahar, "Bureaucratizing Sharia in Modern Indonesia: The Case of Zakat, Waqf and Family Law," Studia Islamika: Indonesian Journal for Islamic Studies, Vol. 26, No. 2 (Agustus, 2019), 207.

${ }^{3}$ Ibid, 206.

${ }^{4}$ Mumung Mulyati, "Kontribusi MUI Dalam Pengembangan dan Penerapan Hukum Islam Di Indonesia," Al-Mashlahah: Jurnal Hukum dan Pranata Sosial Islam, Vol. 07, No. 01 (Agustus 2019), 98.

5 Ibid., 91.

180 Moch. Nurcholis - Kontribusi MUI dalam Rekonfigurasi Hukum Islam 
Penelitian ini bertitik fokus pada sejauh manakah kontribusi MUI dalam upaya rekonfigurasi hukum syariah menjadi hukum positif di Indonesia yang memiliki kekuatan hukum yang mengikat (legal binding) dan dengan cara bagaimanakah upaya tersebut dilakukan. Hasil yang dicapai dari penelitian ini adalah terdeskripsikannya peran MUI dan upaya-upaya yang telah dilakukannya dalam upaya rekonfigurasi hukum syari'ah di Indonesia.

Jenis penelitian ini adalah penelitian pustaka, ${ }^{6}$ yang bersifat normatif. ${ }^{7}$ Paradigma penelitian menggunakan kualitatif dengan pola kerja induktif-deduktif..$^{8}$ Untuk mendapatkan gambaran utuh tentang peran MUI dalam rekonfigurasi hukum syari'ah di Indonesia, penulis akan menggunakan pendekatan perundang-undangan, ${ }^{9}$ pendekatan politik (political approach) dan pendekatam sejarah. ${ }^{10}$

Upaya pengumpulan data penelitian dilakukan dengan cara mencari referensi-referensi di perpustakaan, baik offline maupun online, yang kemudian didokumentasikan dan ditelaah. ${ }^{11}$ Data yang berhasil dikumpulkam kemudia dinanalisa dengan menggunakan teknik content analysis dengan metode deskriptif-analitis. Untuk meminimalisir terjadinya kesalahan dalam penarikan kesimpulan, penulis juga menggunakan teknik analisis Miles dan Hubermen yang disebut dengan “interaktif' dengan model kerja menghubungkan seluruh komponen penelitian berupa pengumpulan data, reduksi data, dan kesimpulan secara siklus-sistemik. ${ }^{12}$

\section{Sejarah MUI}

MUI merupakan organisasi keulamaan dari seluruh umat Islam di Indonesia. Jika pada organisasi keagamaan yang lain, keanggotaanya

\footnotetext{
${ }^{6}$ Data utama yang digunakan dalam penelitian pustaka ini berupa dokumen-dokumen tertulis berupa aturan perundang-undangan yang terkait dengan lembaga MUI. Hasjim Abbas, Metodologi Penelitian Hukum Islam (Jombang: UNDAR Press, 2010), 11.

7 Penelitian normatif ini dilukan dengan menitik fokuskan pada aturan perundangundangan, dalam hal ini aturan perundang-undangan yang dilahirkan atas prakarsa dan keterlibatan MUI. Soerjono Soekanto, Pengantar Penelitian Hukum (Jakarta: UI Press, 2008), 51.

${ }^{8}$ Dalam kerjanya, penulis mencari terlebih dahulu data-data terkait produk fatwa MUI yang telah berkonfigurasi ke dalam bentuk aturan perundang-undangan kemudian mencari landasan hukum apa yang menjadikan MUI telah berhasil berkontribusi dalam upaya pengutan birokratisasi fatwa-fatwa tersebut.

${ }_{9}^{9}$ Peter Mahmud Marzuki, Penelitian Hukum (Jakarta: Kencana, 2010), 194.

${ }^{10}$ Soerjono Soekanto, Penelitian Hukum Normatif (Jakarta: Raja Grafindo Persada, 2012), 14.

11 Mardailis, Metode Penelitian (Jakarta: Bumi Aksara, 2002), 28.

12 Sugiono, Memahami Penelitian Kualitatif (Bandung: Alfabeta, 2009), 95.
} 
secara khusus didasarkan pada kesamaan pandangan, pemahaman dan praktik dalam menjalankan agama sesuai dengan tafsiran atas ajaran agama yang pada akhirnya memunculkan kategoriasi kelompok Islam tradisional- puritan, radikal-liberal, MUI merupakan organisasi yang berfungsi sebagai rumah besar yang beranggotakan atas ulama yang merupakan perwakilan dari beragam organisasi keagamaan tersebut. ${ }^{13}$

Semakin dinamisnya persoalan kehidupan masyarakat di Indonesia, khususnya berkaitan dengan persoalan keagamaan pada satu sisi memerlukan adanya upaya penemuan hukum yang berfungsi sebagai rambu-rambu dalam menghadapi persoalan tersebut, namun di satu sisi seringkali didapati belum adanya teks-teks nash yang secara spesifik menjelaskannya, begitu pula belum terdapat dalam kitab-kitab fikih. Kondisi sosial semacam inilah yang pada akhirnya mendorong adanya keinginan untuk membentuk satu lembaga keagamaan beranggotakan para ulama di Indonesia yang bernama Majelis Ulama Indonesia (MUI), yang salah satu fungsinya adalah untuk merumuskan dan menetapkan hukum terhadap permasalahan-permasalahan baru melalui proses ijtihad jamai (ijtihad kolektif). ${ }^{14}$

Dalam konteks pilitik, berdirinya MUI juga dapat dimaknai sebagai bentuk kepedulian pemerintah terhadap agama dan kehidupan keagamaan di Indonesia sesuai dengan Pancasila sila kesatu. Pemerintah melihat bahwa satu bentuk program keagamaan tidaklah dapat berjalan secara efektif apabila tidak mendapat dukungan dari Negara, begitupula sebaliknya. ${ }^{15}$ Pola hubungan yang baik antara Negara (pemerintah) dan Agama (ulama) harus dijalin dengan baik melalui pembentukan sebuah organisasi keulamaan yang di dalamnya menampung seluruh unsur keulamaan di Indonesia. Lebih dari itu, kondisi organisasi keulamaan yang ada pada saat itu juga masih terkesan berjalan sendiri-sendiri dan belum memiliki cara kerja dan pegangan yang seragam dalam menjalankan sebuah program. Terlebih dalam kurun waktu 1959-1969 peran para ulama dalam konteks perpolitikan cukup melemah seiring dengan diberlakukannya demokrasi terpimpin. Para ulama banyak yang menarik diri dari dunia perpolitikan dan kembali mengkonsentrasikan

\footnotetext{
${ }^{13}$ Dalam dokumen pendirian MUI didapati informasi adanya unsur perwakilan ulama dari organisasi kegamaan atau ormas Islam yang telah terbentuk sebelumnya. MUI, “Sejarah MUI," https://mui.or.id/sejarah-mui/; Diakses tanggal 7 Agustus 2020.

14 Ma'ruf Amin, "Sambutan Ketua Komisi Fatwa dan Hukum Majelis Ulama Indonesia," dalam Himpunan Fatwa Majelis Ulama Indonesia (Jakarta: Dirjen Bimbingan Masyarakat Penyelenggara Haji Kementerian Agama RI, 2003), xi.

15 Pada mulanya MUI dirikan untuk menopang program-program pemerintah khususnya yang berkaitan dengan umat Islam. Ainul Rokhim Faqih, et al., HKI, Hukum Islam dan Fatwa MUI (Yogyakarta: Graha Ilmu, 2010), 35.

182 Moch. Nurcholis - Kontribusi MUI dalam Rekonfigurasi Hukum Islam
} 
diri sebagai pengajar di pesantren (Kyai, Pengasuh Pesantren) dan menjadi muballigh. ${ }^{16}$

Setelah didahului dengan musyawarah para ulama pada bulan Juli tahun 1975 dengan Letjen (Purn.) H. Soedirman sebagai ketua panitianya, ${ }^{17}$ MUI dinyatakan telah berdisi secara resmi, sejak 26 Juli 1975 yang ditandai dengan penandatanganan "Piagam Berdirinya Majelis Ulama Indonesia (MUI) ${ }^{18}$ MUI resmi berdiri sebagai lembaga keulamaan di Indonesia dengan H. Abdul Karim Amrullah (Hamka) sebagai Ketua Umum pertama. ${ }^{19}$ Dengan berdirinya MUI maka bangsa Indonesia telah memiliki wadah yang mampu mengakomodir dan mensinergikan seluruh pendapat dan pemikiran ulama Indonesia yang tersebar di berbagai daerah. ${ }^{20}$ Dengan bahasa yang lebih sederhana, MUI adalah wadah koordinasi dan konsolidasi seluruh ulama yang ada di Indonesia.

\section{Kedudukan Lembaga MUI di Indonesia}

Sebagaimana telah dibahas sebelumnya, pada mulanya MUI dibentuk oleh prakarsa pemerintah, selain sebagai bentuk perhatian pemerintah terhadap umat Islam Indonesia, juga berfungsi sebagai penyambung gagasan-gagsan dan program-program pembangunan nasional kepada masyarakat. Hal ini sebagaimana tampak jelas dalam sambutan Presiden Soeharto saat membuka kegiatan Munas MUI yang pertama kali di Istana Negara. Presiden mengemukakan bahwa tugas yang harus dijalankan oleh MUI adalah melakukan upaya memerintah kebaikan dan mencegah kemunkaran (al-amr bi al-ma'ruf wa al-naby 'an almunkar). Kaitan hubungan dengan pemerintahan, MUI hendaknya dapat berperan sebagai penyambung program-program pemerintah sekaligus

\footnotetext{
${ }^{16}$ M. Atho Mudzhar, Fatwa-Fatwa Majelis Ulama Indonesia: Sebuah Studi Tentang Pemikiran Hukum Islam di Indonesia 1975-1988 (Jakarta: INIS, 1993), 54.

17 Musyawarah ulama ini sebenarnya merupakan upaya lanjutan dari usulan yang sebelumnya pernah diajukan oleh Pusat Dakwah Islam saat berlangsungnya konferensi ulama yang bertempat di Jakarta tahun 1970. Pusat Dakwah Islam berpandangan adanya kemendesakan pembentukan sebuah majelis keulamaan di Indonesia yang secara khusus bertugas memberikan fatwa-fatwa hukum. Hal ini diperlukan agar dapat memajukan dan mempersatukan umat Islam Indonesia dalam menghadapi kondisi dan tantangan social yang ada seiring dengan melemahmahnya peran ulama dalam konteks politik formal. Deliar Noer, The Administration of Islam in Indonesia (New York: Cornell Modern Indonesia Projeck, 1978), 72; Lihat juga dalam Departemen Penerangan RI, 10 Tabun Majelis Ulama Indonesia: 26 Juli 1975-26 Juli 1985 (Jakarta: Departemen Penerangan RI, 1985), 15.

${ }_{18}$ MUI Jawa Timur, Pedoman Penyelenggaraan Organisasi Majelis Ulama Indonesia (Surabaya: MUI Jawa Timur, 2013), 7.

${ }^{19}$ Helmi Karim, Konsep Ijtihad Majelis Ulama Indonesia (Pekanbaru: Suska Press, 1994), 9.

${ }^{20}$ MUI Provinsi Jawa Timur, Pedoman Penyelenggaraan Organisasi, 7.
} 
memeberikan masukan terkait hal-hal yang berhubungan dengan kehidupan beragama di Indonesia. Presiden juga mengaharapkan peran aktif MUI dalam proses transformatif pada masyarakat menuju ke arah yang lebih baik. ${ }^{21}$

Lebih jauh daripada sekedar fungsi penyampai program-program pemerintah, Atho Mudzhar menyebutkan bahwa tujuan awal dibentuknya MUI juga untuk kepentingan-kepentingan praksis rezim pemerintah untuk meraup suara umat Islam pada pemilu tahun 1971. Hal ini, menurut Atho, terbaca secara jelas dari kejadian-kejadian penting yang meliputi proses pembentukan MUI. Dalam tataran kronologis, upaya mendirikan MUI sudah dimulai sejak tahun 1970, yakni satu tahun menjelang pemilu. Selain itu, upaya pemerintah untuk mengendalikan umat Islam sangatlah tampak pada 1973, ketika pemerintah mendesak agar partai-partai politik menghapus identitas dan sebutan 'Islam" serta menyatukan diri dalam satu partai politik tertentu, hal mana juga berlaku untuk partai-partai politik berhaluan nasionalis. ${ }^{22}$

Dalem fase awal ini, keberadaan MUI mendapatkan sambutan pro dan kontra dari masyarakat muslim. Hal ini terjadi sebab pada saat itu sedang menerapkan kebijakan pembatasan ruang gerak partai-partai politik, termasuk partai politik Islam. Dalam kondisi sosial semacam inilah muncul satu kesan ditengah-tengah masyarakat bahwa MUI sengaja dibentuk oleh pemerintah dengan tujuan membatasi ruang gerak ormas-ormas Islam yang ada. Dalam merespons kondisi ini, program utama MUI lebih banyak didominasi kegiatan-kegiatan sosialisasi dan pengenalan identitas kepada masyarakat Indonesia dan masyakarat dunia. Seiring dengan berjalannya waktu, kecurigaan masyarakat tersebut tidaklah sepenuhnya terbukti. Anggapan bahwa MUI adalah lembaga pelabelan program-program pemerintah tidaklah dapat dibenarkan sepenuhnya, ${ }^{23}$ sekalipun pandangan tersebut ditujukan pada fase awal

\footnotetext{
${ }^{21}$ Ibid., 8.

22 Mudzhar, Fatwa-Fatwa Majelis, 71.

${ }^{23}$ Hubungan antara MUI dan Pemerintah sebenarnya cukup rumit. Di fase-fase awal MUI memang selalu di bawah tekanan Pemerintah untuk membela programprogramnya. Hal ini sebagaimana tergambar dalam kasus pencabutan fatwa haram penggunaan alat kontrasepsi IUD (Intra Uterine Devices) sebagai hasil konferensi ulama di Jakarta pada tahun 1983 yang didanai oleh Departemen Agama dan BKKBN. Konferensi ini merupakan respons atas fatwa haram penggunakan alat kontrasepsi yang sebelumnya pernah diterbitkan oleh sekolompok ulama pada tahun 1971. Fatwa haram ini oleh pemerintah dianggap dapat menghambat program keluarga berencana dan oleh karenanya perlu dibatalkan melalui fatwa baru yang dikeluarkan oleh MUI. Titin Hamidiyah, Perkembangan MUI Kota Surabaya: 1975-1992 (Surabaya: IAIN Surabaya Press, 2009), 194.

184 Moch. Nurcholis - Kontribusi MUI dalam Rekonfigurasi Hukum Islam
} 
pembentukannya sebagaimana terbukti dari sikap Ketua Umum pertama MUI, H. Abdul Karim Amrullah (Hamka) yang memilih melepaskan jabatannya sebab adanya perselisihan pandangan dengan Menteri Agama. Surat pengunduran diri Hamka tertanggal 18 Mei 1981 itu ditulis sendiri olehnya yang kemudian diketik oleh anaknya, yakni Rudi Hamka. ${ }^{24} \mathrm{Hal}$ ini juga diperkuat dengan adanya sikap kritis MUI terhadap program BPJS Kesehatan yang dijalankan oleh pemerintah pada tahun 2015. ${ }^{25}$

Dalam konteks ketatanegaraan di tanah air, kategori struktur kenegaraan terbagi menjadi dua. Kategori pertama adalah infrastruktur, yakni satu lembaga yang dari sisi luar tidak tampak kehidupan politiknya, akan tetapi memiliki fungsi yang nyata dalam sebuah kehidupan bernegara. Peran dan kontribusi dalam kelompok pertama ini hanya dengan cara menyelami kehidupan masyarakat secara langsung. Infastruktul diantaranya terdiri atas media massa, tokoh politik, kelompok penekan, partai politik, LSM, dan organisasi kemasyarakatan. ${ }^{26}$ Sedangakn kelompok kedua adalah suprastruktur (the goverment political sphere), yakni kehidupan politik yang dapat terlihat dari luar. Keterlihatannya diukur dari program-program yang secara langsung dapat dirasakan dan terlihat kasat mata oleh masyarakat. Masuk dalam kelompok ini adalah lembaga-lembaga negara yang oleh Undang-Undang 1945 diberi wewenang dan kekuasaan untuk menjalankan tugas dan fungsi negara, yakni MPR. DPR, Presiden (pemerintah), DPD, MA, MK, dan $K Y^{27}$

Jika ditinjau dalam ketatanegaraan tersebut di atas, MUI dapat dikategorikan sebagai infrastruktul. Sebab ranah pengabdian MUI lebih pada ranah pemberdayaan masyarakat, khususnya umat Islam. Artinya, MUI merupakan lembaga yang hidup ditengah-tengah masyarakat dan bukan lembaga milik Negara yang memiliki kedaulatan memaksa bagi segenap rakyat. Jika dilihat lebih jauh, keberadaan MUI dalam kelompok infrastruktur masuk dalam jenis kelompok penekan atau kelompok kepentingan institusional (interest group institusional). Tipilogi kelompok ini ditandai dengan adanya proses persatuan oleh sekolompok orang tertentu sebab adanya kepentingan-kepentingan yang ingin diwujudkan, baik kepentingan yang bersentuhan dengan kelompok itu sendiri maupun untuk kepentingan masyarakat luas. Sebagai kelompok kepentingan

\footnotetext{
${ }^{24}$ Rusdi Hamka, Pribadi dan Martabat Buya Hamka (Jakarta: Noura Books, 2017), 196.

${ }^{25}$ Majelis Ulama Indonesia, "Pemerintah-MUI Sepakat BPJS Kesehatan Direvisi Agar Sesuai Syariah," https://mui.or.id/berita/569/; Diakses tanggal 7 Agustus 2020.

26 Wawan Risnawan, "Peran dan Fungsi Infrastruktur Politik dalam Pembentukan Kebijakan Publik,” Dinamika, Vol. 4, No. 3 (September, 2017), 514.

${ }^{27}$ Ibid., 517.
} 
institusional, MUI yang merupakan wadah perkumpulan ulama dari berbagai organisasi keagamaan, dalam hal ini seperti NU, Muhammadiyah, Dewan Masjid Indonesia, PERTI, SI, Al-Wasliyah, Mathlaul Alwar, PDTI, GUPPI, dan al-Ittihadiyah. Lebih dari itu, keberadaan MUI sebagai infrastruktul juga ditegaskan sendiri oleh Presiden Soeharto yang secara khusus memberikan arahan agar MUI tidak melibatkan diri dalam kegiatan-kegiatan bersifat praktis lebih-lebih melibatkan diri dalam kegiatan-kegiatan politik praktis. ${ }^{28}$

\section{Fatwa MUI Dan Kedudukannya dalam Pembinaan Hukum di Indonesia}

Secara bahasa fatwa adalah nasehat atau juga dapat disebut sebagai jawaban atas sebuah permasalahan hukum. Sedangkan secara istilah fatwa dapat diartikan sebagai pendapat hukum yang ditemukan yang sifatnya tidak mengikat dan tidak memiliki daya paksa dalam tataran implementasi. ${ }^{29}$ Al-Qarafi mengatakan bahwa fatwa merupakan keterangan hukum Agama, baik yang bersifat mengikat ataupun tidak. ${ }^{30}$ Sedangkan menurut Ibn Hamdan, fatwa merupakan penjelasan tentang hukum syara' yang bersunder dari dali-dalil syar'i. ${ }^{31}$ Secara lebih rinci, alQardlawi menyatakan bahwa fatwa adalah penjelasan tentang hukum syara' atas sebuah masalah agama yang diajukan oleh peminta fatwa secara individual atau komunal. ${ }^{32}$

Dari seluruh penjelasan definisi fatwa sebagaimana disebutkan, diketahui bahwa fatwa merupakan kumpulan tentang hukum syariah yang ditetaokan oleh faqih secara probadi atau sebuah institusi yang memiliki kapasitas dan kapabelitas sebagai bentuk respons atas pertanyaan orang yang meminta fatwa, baik yang bersifat mengikat atupun tidak mengikat.

Sejak zaman kolonial, produk fatwa merupakan satu hal yang penting bagi masyarakat dalam menjalam persoalan keagamaan, khususnya bagi masyarakat muslim. ${ }^{33}$ Corak fatwa dalam rentangan abad

\footnotetext{
${ }^{28}$ Mudzhar, Fatwa-Fatwa Majelis, 63.

${ }^{29}$ Abdul Aziz Dahlan, at al., "Fatwa", Eksiklopedi Hukum Islam (Jakarta: Ichtiar Baru van Hoeve, 1996), 326.

30 Syihabuddin al-Qarafi, Al-D zakirah (Beirut: Dar al-Gharb al-Islami, 1994), 121.

31 Ahmad Ibn Hamdan, Sifat al-Mufti wa al-Mustafti (Beirut: Al-Maktab Al-Islami, 1977), 4.

32 Yusuf al-Qardlawi, Al-Fatwa bayn al-Indhibath wa al-Tasayyub (Kairo: Dar al-Shafwah li al-Nashr, 1988), 11.

33 Wildan Imaduddin Muhammad, "Keberanjakan Fatwa dari Legal Opinion Menjadi Legal Binding: Studi Kasus Fatwa DSN MUI Tentang Perbankan Syariah," Jurisprudensi, Vol. 11, No. 2 (November, 2019), 147.

186 Moch. Nurcholis - Kontribusi MUI dalam Rekonfigurasi Hukum Islam
} 
19 dan 20, sebagaimana diungkap oleh Nico J.G. Kaptein, terkategori dalam tiga corak utama, yakni; Pertama, fatwa individu bercorak tradisionalis. Kedua, fatwa individu bercorak modernis. Ketiga; fatwa komunal yang diterbitkan oleh lembaga-lembaga keagamaan di Indonesia. Untuk memperkuat tesisnya ini, Nico, memberikan contoh bentuk fatwa yang dikeluarkan pada rentangan abad tersebut. Pertama, manuskrip kitab dengan judul mubimmat al-nafais fi bayan as'ilat al-hadits yang berisi fatwa-fatwa dari beberapa ulama. Manuskrip ini dianggap sebagai mewakili produk fatwa dari jenis fatwa individual bercorak tradisional. Kedua, buku dengan judul soal jawab karya A. Hassan yang merupakan buku himpunan fatwa bersumber dari majalah Pembela Islam periode 1929-1935. Buku ini merupakan representasi dari fatwa individual bercorak modernis. Ketiga, buku himpunan hasil bahtsul masail NU (1926), fatwa majelis tarjih Muhammadiyah (1912), fatwa Majelis Ulama Indonesia (1975)..$^{34}$

Mengacu pada pengkelompokkan yang dilakukan oleh Nico ini, maka keberadaan fatwa MUI merupakan produk fatwa komunal atau fatwa kolektif. Kesimpulan ini juga dibenarkan oleh sendiri oleh MUI melalui pengakuan ketua komisi fatwa dan hukum MUI pada tahun 2013 sebagaimana tertuang dalam kata sambutan buku himpunan fatwa MUI. Ma'ruf Amin, yang saat itu menjabat sebagai ketua komisi fatwa mengatakan bahwa produk fatwa MUI merupakan produk fatwa ijtihad jama'i dengan menggunakan metodologi penemuan hukum yang telah disediakan oleh fuqaha. ${ }^{35}$

Prosedur penerbitan fatwa terkait persoalan keagamaan masyarakat muslim di Indonesia, MUI sebagaimana diungkapkan Amin, pada dasarnya hanyalah memilih ragam pendapat ulama fikih yang telah telah terkoleksikan dalam bentuk kitab-kitab fikih atau lumrah disebut kitab kuning. Hal ini dilakukan sejauh persoalan tersebut masih terjangkau oleh pendapat-pendapat ulama fikih yang ada. Sebaliknya, dalam persoalan yang belum ada jawaban secara spesifik di dalam kitab-kitab fikih, maka MUI berijtihad secara kolektif untuk merumuskan jawaban hukumnya. ${ }^{36}$ Dalam permasalahan yang kedua ini, meski tidak sama persis, fatwa MUI sebenarnya juga dapat disebut sebagai produk hukum

\footnotetext{
34 Nico J.G. Kaptein, "The Voice of Ulama: Fatwas and Religious Authority in Indonesia," Archives de Sciences Sociales des Religions, 125 (Maret, 2004), 130.

${ }^{35}$ Amin, "Sambutan Ketua Komisi Fatwa", xi.

36 Ibid.
} 
yang dihasilkan melalui proses ijtihad dengan menggunakan metode ijma' (konsensus). ${ }^{37}$

Secara lebih detail tahapan perumusan dan penetapan fatwa MUI dilakukan melalui tahapan-tahapan sebagaimana berikut; Pertama, melakukan pelacakan dan peninjauan terhadap pendapat-pendapat ulama madzhab fikih terkait persoalan yang dimintakan fatwa beserta dengan dalil-dalil yang digunakannya. Kedua, persoalan yang telah memiliki hukum secara jelas dan telah disepakati oleh seluruh ulama mazhab (almasail al-qath'iyyah), maka langsung dapat diumumkan. Ketiga, ketika persoalan tersebut memiliki beberapa ragam pendapat dari ulama mazhab, maka dilakukan proses al-jam'u wa al-tawfiq (langkah kompromistis diantara ragam pendapat dengan jalan menemukan titik persamaannya dan perbedaannya), jika tidak berhasil maka dilakukan upaya tarjih (penegasian ketentuan hukum tertentu atas yang lain) dengan melalui metode kaidah-kaidah ushul figh (legal formal theori). Keempat, jika persoalan yang dimintakan fatwa belum ditemukan jawaban hukumnya di kitab-kitab fikih, maka dilakukan upaya ijtihad jama'i (usaha penemuan hukum secara kolektif) melalui metode bayani, ta'lili, istishlabi, dan sadd aldzariah. Kelima, keseluruhan upaya penemuan hukum tersebut harus senantiasa berdasar pada aspek kemashlatan umum dan maqashid alsyari'ab (tujuan-tujuan penetapan hukum syari'ah). ${ }^{38}$ Selain tahapantahapan tersebut, dalam persoalan yang kiranya membutuhkan satu pertimbangan dari ahli dari bidang kajian tertentu, hendaknya juga menghadirkan tenaga ahli sebagai bahan pertimbangan pengambilan dan penetapan fatwa. ${ }^{39}$

Produk fatwa yang telah ditetapkan kemudian diumumkan kepada masyarakat umum agar dapat menjadi panduan dalam menyikapi persoalan yang dimintakan fatwa tersebut. Secara bentuk lahiriah, produk fatwa MUI dimulai dengan keterangan waktu pelaksanaan sidang terkait dengan pertanyaan yang diajukan. Kemudian dilanjutkan dengan keterangan konsiderensi dan isi fatwa. Pada bagian akhir disebutkan tempat dan tanggal penetapan dan diakhiri dengan pengesahan oleh Ketua dan Sekretaris komisi fatwa MUI. ${ }^{40}$

\footnotetext{
${ }^{37}$ Andi Fariana, "Urgensi Fatwa MUI Dalam Pembangunan Sistem Hukum Ekonomi Islam di Indonesia," Al-Ihkam: Jurnal Hukum dan Pranata Sosial, Vol. 12, No. 1 (Juni, 2017), 101.

${ }^{38}$ MUI Provinsi Jawa Timur, Pedoman Penyelenggaraan Organisasi, 119.

${ }^{39}$ Lihat dalam Pasal 2 Angka 4 Pedoman Penetapan Fatwa Majelis Ulama Indonesia Nomor: U-596/MUI/X/1997.

40 Lihat misalnya dalam lembaran keputusan fatwa MUI tentang Penanggulangan Penularan HIV/AIDS. Kementerian Agama RI, Himpunan Fatwa Majelis Ulama Indonesia 188 Moch. Nurcholis - Kontribusi MUI dalam Rekonfigurasi Hukum Islam
} 
Kedudukan fatwa MUI dalam konteks pembinaan hukum di Indonesia dapat ditentukan dengan melihat ketentuan yang termuat dalam Undang-Undang Nomor 12 tahun 2011 tentang Pembentukan Peraturan Perundang-Undangan. Dalam Bab Pasal 1 Angka 2 menyatakan bahwa sebuah norma hukum baru dapat memiliki kekuatan yang mengikat apabila norma tersebut telah ditetapkan oleh lembaga negara atau pejabat yang berwenang menjadi aturan tertulis melaluhi tahapan-tahapan yang telah ditetapkan oleh aturan perundangundangan. ${ }^{41}$

Sedangkan dalam Pasal 7 ayat (1) dan ayat (2) menjelaskan tentang jenis dan hierarki serta kekuatan hukum peraturan perundang-undangan yang berlaku di Indonesia, yakni UUD 1945, Tap MPR, UU/Perppu, PP, Perpres, Perda Provinsi, dan Perda Kabupaten/Kota. Kekuatan hukum dari seluruh peraturan perundang-undangan tersebut disesuaikan dengan hierarkinya. ${ }^{42}$ Selain yang telah disebutkan dalam Pasal 7 tersebut, dalam Pasal 8 ayat (1) juga disebutkan tentang peraturan perundang-undangan lain yang juga memiliki kekuatan hukum mengikat, yakni peraturan yang ditetapkan oleh MPR, DPR, DPD, MA, MK, BPK, KY, BI, Menteri, Lembaga setingkat Menteri, DPRD Provinsi, Gubernur, DPR Kabupaten/Kota, Bupati/Walikota, dan Kepala Desa. ${ }^{43}$

Mencermati isi pasal-pasal di atas, tampak jelas bahwa aturan perundang-undangan yang memiliki daya paksa dan mengikat secara umum mempersyaratkan dikeluarkan oleh lembaga negara. Sedangakn MUI, sebagaimana telah dijelaskan pada pembahasan sebelumnya termasuk dalam kategori infastruktur yang hidup ditengah-tengah masyarakat dan bukan termasuk sebagai lembaga negara. Dengan demikian, fatwa MUI bukan termasuk dalam kategori aturan mengikat yang harus ditatai oleh seluruh rakyat Indonesia dan memiliki sanksi tertentu. ${ }^{44}$ Mahfud MD dalam satu kesempatam wawancara mengatakan bahwa fatwa MUI merupakan fatwa keagmaan dan hanya mengikat secara pribadi. Fatwa MUI bukan merupakan hukum positif yang harus

(Jakarta: Dirjen Bimbingan Masyarakat Penyelenggara Haji Kementerian Agama RI, 2003), 213.

41 Pasal 1 Angka 2 Undang-Undang Nomor 12 Tahun 2011 tentang Pembentukan Peraturan Perundang-Undangan

42 Pasal 7 Undang-Undang Nomor 12 Tahun 2011 tentang Pembentukan Peraturan Perundang-Undangan

43 Pasal 8 Undang-Undang Nomor 12 Tahun 2011 tentang Pembentukan Peraturan Perundang-Undangan

44 Ainun Najib, "Fatwa Majelis Ulama Indonesia Dalam Perspektif Pembangunan Hukum Responsif," Lisan al-Hal: Jurnal Pengembangan Pemikiran dan Kebudayaan, Vol. 4, No. 2 (Desember, 2012), 375. 
ditakuti dan ditaati. Dengan sifatnya yang berlaku secara pribadi, fatwa MUI tidak boleh dijadikan dasar dalam pemberian hukuman dan sanksi bagi para pelanggarnya. ${ }^{45}$ Namun demikian, dalam tataran empirik, fatwa MUI acapkali dijadikan sebagai pedoman dalam berbagai aktifitas masyarakat, khususnya yang bersentuhan dengan aspek keagamaan, seperti status halal-hatram sebuah produk. Lebih dari itu, sejak lahirnya Dewan Syariah Nasional (DSN) MUI pada tahun 1998, fatwa MUI, dalam konteks aktifitas ekonomi syariah, telah bertransformasi kedalam aturan perundang-undangan (seperti peraturan Bank Indonesia dan OJS) yang dijadikan dasar dalam mengatur aktifitas ekonomi berbasis syariah di Indonesia. ${ }^{46}$

\section{MUI dan Rekonfigurasi Hukum Islam di Indonesia: Membaca Peran MUI dalam Birokatrisasi Syariah di Indonesia}

Birokatrisasi syariah di Indonesia seringkali disalahpahami sebagai proyek Syariatisasi dan Islamisasi terhadap hukum Negara. Pandangan demikian sebagaimana diungkapkan oleh Arskal Salim, Zachari Abuza, Mitsuo Nakamura, Robin Bush, Michael Buehler. ${ }^{47}$ Hal ini muncul terakibatkan dari diskursus syariah vis a vis negara yang tidak kunjung usai dan nampak akan menjadi agenda abadi dalam setiap memperbincangkan hubungan antara negara dan agama. ${ }^{48}$

Birokratisasi merupakan institusionaliasi yang merupakan rasionaliasi dari beragam sistem kehidupan yang ada yang bersumber dari nilai-nilai, keyakinan, dan tradisi dapat dimaknai sebagai respons terhadap kehidupan modern demi terwujudnya satu relasi yang harmonis dan adil. Birokratisasi syariah di Indonesia yang dilakukan secara eklusif sebagai bentuk mewujudkan pelayanan administratif urusan keagamaan yang terkait dengan masyarakat luas. Upaya ini diperlukan untuk menjamin legalitas dan keteraturan pelaksanaan aktifitas keagamaan yang dilakukan oleh masyarakat muslim sesuai dengan hukum fikih yang telah lama hidup (living law) di tengah-tengah masyarakat. Hal ini tentu berbeda dengan model Syariatiasi atau Islamisasi yang mengandaikan adanya

45 Moh. Mahfud MD, "Apakah Fatwa MUI Harus Fiikuti? Tentu Tidak," https://news.detik.com/berita/d-3397842/; Diakses tanggal 8 Agustus 2020.

${ }^{46}$ Fariana, "Urgensi Fatwa MUI", 106.

47 Jahar, "Bureaucratizing Sharia in Modern Indonesia," 210.

48 Marzuki Wahid, "Legislasi Syari'at Islam Dalam Negara Pancasila," (Makalah Tidak Diterbitkan -- Disampaikan dalam Kegiatan Tadarus Litapdimas Dirjen Pendis Kemenag RI Seri 7, 14 Mei 2020), 1.

190 Moch. Nurcholis - Kontribusi MUI dalam Rekonfigurasi Hukum Islam 
penggatian aturan yang dan diganti dengan aturan yang bersesuaian dengan syariat Islam. ${ }^{49}$

Dalam upaya birokratisasi semacam itulah kehadiran MUI, sebagai lembaga keulamaan di Indonesia, sangat terasa peran dan kehadirannya. Kehadiran MUI dalam konteks ini berperan sebagai infastruktur resmi yang dapat berfungsi sebagai pengatur interrrelasi dan partisipasi publik. MUI telah mampu berperan sebagai pendorong sekaligus sebagai lembaga penerbit rekomendasi dalam proses rekonfigurasi hukum Islam di Indonesia, dari semula yang hanya berwujud hukum tidak tertulis menjadi hukum tertulis.

Telah banyak produk-produk fatwa MUI yang pada mulanya hanya bersifat hukum tidak tertulis telah dan sedang berproses menjadi aturan perundang-undangan yang bersifat mengikat dan memiliki sanksi apabila dilanggar. Diantara produk fatwa MUI yang telah berkonfigurasi menjadi aturan perundang-undangan adalah RUU Jaminan Produk Halal; UU No. 21 Tahun 2008 tentang Perbankan Syariah; UU No. 44 Tahun 2008 tentang Pornografi; PP No. 15 Tahun 2014 tentang Syarat dan Tatacara Perizinan Pembuatan, Penyebarluasan, dan Penggunaan Produk Pornografi; RUU Hukum Materiil Peradilan Agama dalam Bidang Perkawinan; UU No. 41 Tahun 2004 tentang Wakaf; PP No. 42 Tahun 2006 tentang Pelaksanaan UU No. 41 Tahun 2004 tentang Wakaf; UU No. 13 Tahun 2008 tentang Penyelenggaraan Ibadah Haji; Peraturan Mahkamah Agung Nomor 2 Tahun 2008 tentang KHES; PP No. 55 Tahun 2007 tentang Pendidikan Agama dan Keagamaan; RUU tentang Pemilu Kepala Daerah; RUU tentang KUHP; RUU tentang Kesetaraan dan Keadilan Gender; RUU tentang Kerukunan Umat Beragama; RUU tentang Perguruan Tinggi; RPP tentang Kedudukan Anak sebagai Pelaksana Undang-Undang Perkawinan; Amandemen UUD 1945, dan peraturan tentang program BPJS Kesehatan. ${ }^{50}$

Kontribusi MUI dalam upaya rekonfigurasi hukum Islam melalui birokatrisasi syariah di Indonesia dilakukan melalui beberapa cara. Diantaranya dilakukan dengan cara memberikan dukungan terhadap kelahiran aturan perundang-undangan tertentu. Dalam kasus UU Pornografi, misalnya, MUI dengan bersama organisasi-organisasi keagamaan lainnya berada dalam barisan utama pendukung lahirnya Undang-Undang Poronografi tersebut. ${ }^{51}$

Selain dengan cara memberikan dukungan atas lahirnya sebuah aturan perundang-undangan, MUI juga secara aktif memberikan usulan-

\footnotetext{
49 Jahar, "Bureaucratizing Sharia in Modern Indonesia," 209.

${ }^{50}$ Mulyati, "Kontribusi MUI Dalam Pengembangan," 98.

${ }^{51}$ Ibid., 97.
} 
usulan dan kritik ketika sebuah aturan perundang-undangan tertentu muncul. Sebagai misal, ketika muncul pro dan kontra terkait program BPJS Kesehatan menyangkut keabsahannya dalam pandangan hukum Islam, MUI hadir dengan sikap kritis terhadap program pemerintah tersebut. Saat itu, MUI berpandangan bahwa program BPJS Kesehatan yang dijalankan Pemerintah tidak sesuai dengan ketentuan Syari'ah sebagaimana berdasarkan hasil Munas Ulama MUI tahun 2015 di Tegal. Pada akhirnya, setelah terjadi pertemuan bersama antara MUI, Pemerintah, DJSN, OJK dan BPJS Kesehatan dicapailah kesepakatan untuk mengadakan pembahasan lebih lanjut terkait program tersebut agar bersesuaian dengan prinsip-psinsip syariah. ${ }^{52}$ Sikap kritis dan koreksi MUI terhadap Pemerintah ini dapat dijadikan bukti bahwa MUI telah menjalankan salah satu fungsi dan perannya sebagai pemberi fatwa mengenai masalah keagamaan dan kemasyarakatan kepada pemerintah dan umat Islam umumnya demi mewujudkan masyarakat yang agamis dan adil. ${ }^{53}$

Upaya rekonfigurasi hukum Islam di Indonesia oleh MUI, selain menggunakan dua cara di atas, juga dilakukan dengan cara memberikan fatwa syariah. Hal ini tampak, khususnya dalam permasalahan kegiatan perekonomian dan perbankan berbasis syariah di Indonesia, dengan terbentuknya salah satu sub bidang lembaga MUI bernama Dewan Syariah Nasional-Majelis Ulama Indonesia (DSN-MUI) yang secara khusus menangani permasalahan ekonomi syariah. ${ }^{54}$

Peran dari DSN-MUI ini bahkan telah terlegitimasi dalam aturan perundang-undangan di Indonesia, yakni Undang-Undang Nomor 21 Tahun 2008 Tentang Perbankan Syariah (UUPS), khusunya dalam Pasal 1 ayat (12), Pasal 26 ayat (2) dan Pasal 32 ayat (2). ${ }^{55}$ Lebih dari itu, regulator dalam hal ini Bank Indonesia diwajibkan untuk menyerap dan mentransformasikan produk fatwa DSN MUI dalam menyusun rumusan prinsip-prinsip syariah dalam bidang ekonomi syariah. Hal ini sebagaimana ditegaskan dalam Pasal 26 ayat (1), ayat (2), dan ayat (3) UUPS. ${ }^{56}$ Diakuinya DSN-MUI sebagai lembaga yang memiliki legitimasi menerbitkan fatwa dalam bidang kegiatan perekonomian berbasis syariah

\footnotetext{
52 Majelis Ulama Indonesia, "Pemerintah-MUI Sepakat BPJS Kesehatan Direvisi Agar Sesuai Syariah,” https://mui.or.id/berita/569/; Diakses tanggal 7 Agustus 2020.

53 Pasal 4 Anggaran Dasar Majelis Ulama Indonesia (MUI).

54 Mohammad Zamroni, "Peran DSN-MUI Dalam Kegiatan Perbankan Syariah," Tasyri: Jurnal Tarbiyah Syariah Islamiyah, Vol. 25 No. 1 (April 2018), 46.

${ }^{55}$ Lihat Pasal 26 ayat (2) dan Pasal 32 ayat (2) Undang-Undang Nomor 21 Tahun 2008 tentang Perbankan Syariah.

${ }^{56}$ Lihat Pasal 26 ayat (1), ayat (2), dan ayat (3) Undang-Undang Nomor 21 Tahun 2008 tentang Perbankan Syariah.

192 Moch. Nurcholis - Kontribusi MUI dalam Rekonfigurasi Hukum Islam
} 
di Indonesia memberi arah baru terkait kekuatan hukum dari fatwa itu sendiri, dari yang semula berwujud legal opinion menjadi wujud legal binding. $^{57}$

\section{Kesimpulan}

Upaya rekonfigurasi hukum Islam di Indonesia oleh MUI dilakukan melalui birokratisasi syariah. Birokatratisasi syariah dalam hal ini dimaknai dengan sebuah upaya melegalformalkan hukum-hukum Islam yang telah hidup di masyarakat (living law) yang semula masih berwujud hukum tidak tertulis menjadi hukum tertulis yang memiliki kekuatan hukum mengikat.

MUI telah berperan secara signifikan dalam rekonfigurasi hukum Islam di Indonesia dengan indikasi telah terbitnya beberapa aturan perundang-undangan yang sesungguhnya berasal dari produk-produk fatwa. Dalam upaya ini, MUI melakukannya melalui tiga cara, yakni; Pertama, memberikan dukungan terhadap kelahiran aturan perundangundangan tertentu; Kedua, memberikan dukungan dan koreksi krtisi terhadap aturan perundang-undangan yang telah terbit; Ketiga, memberikan fatwa syariah.

57 Ahyar A. Gayo, at al., "Hukum Tentang Kedudukan Fatwa MUI Dalam Upaya Mendorong Pelaksanaan Ekonomi Syariah," (Laporan Penelitian -- Badan Pembinaan Hukum Nasional Kementerian Hukum dan HAM RI, 2011), xxxvi. 


\section{Daftar Pustaka}

Abbas, Hasjim. Metodologi Penelitian Hukum Islam. Jombang: UNDAR Press, 2010.

Amin, Ma'ruf Amin. "Sambutan Ketua Komisi Fatwa dan Hukum Majelis Ulama Indonesia," dalam Himpunan Fatwa Majelis Ulama Indonesia. Jakarta: Dirjen Bimbingan Masyarakat Penyelenggara Haji Kementerian Agama RI, 2003.

Anggaran Dasar Majelis Ulama Indonesia (MUI).

Dahlan, Abdul Aziz, at al. Eksiklopedi Hukum Islam. Jakarta: Ichtiar Baru van Hoeve, 1996.

Departemen Penerangan RI. 10 Tabun Majelis Ulama Indonesia: 26 Juli 1975-26 Juli 1985. Jakarta: Departemen Penerangan RI, 1985.

Faqih, Ainul Rokhim, et al., HKI, Hukum Islam dan Fatwa MUI. Yogyakarta: Graha Ilmu, 2010.

Fariana, Andi. "Urgensi Fatwa MUI Dalam Pembangunan Sistem Hukum Ekonomi Islam di Indonesia." Al-Ibkam: Jurnal Hukum dan Pranata Sosial, Vol. 12, No. 1 (Juni, 2017).

Gayo, Ahyar A. at al. "Hukum Tentang Kedudukan Fatwa MUI Dalam

Upaya Mendorong Pelaksanaan Ekonomi Syariah.” (Laporan Penelitian -- Badan Pembinaan Hukum Nasional Kementerian Hukum dan HAM RI, 2011).

Hamdan, Ahmad Ibn. Sifat al-Mufti wa al-Mustafti. Beirut: Al-Maktab AlIslami, 1977.

Hamidiyah, Titin. Perkembangan MUI Kota Surabaya: 1975-1992. Surabaya: IAIN Surabaya Press, 2009.

Hamka, Rusdi. Pribadi dan Martabat Buya Hamka. Jakarta: Noura Books, 2017.

Jahar, Asep Saepudin. "Bureaucratizing Sharia in Modern Indonesia: The Case of Zakat, Waqf and Family Law." Studia Islamika: Indonesian Journal for Islamic Studies, Vol. 26, No. 2 (Agustus, 2019).

Kaptein, Nico J.G. "The Voice of Ulama: Fatwas and Religious Authority in Indonesia." Archives de Sciences Sociales des Religions, No. 125 (Maret, 2004).

Karim, Helmi. Konsep Ijtihad Majelis Ulama Indonesia. Pekanbaru: Suska Press, 1994.

Kementerian Agama RI. Himpunan Fatwa Majelis Ulama Indonesia. Jakarta: Dirjen Bimbingan Masyarakat Penyelenggara Haji Kementerian Agama RI, 2003. 
Mahfud MD, Moh. "Apakah Fatwa MUI Harus Fiikuti? Tentu Tidak." https://news.detik.com/berita/d-3397842/. Diakses tanggal 8 Agustus 2020.

Majelis Ulama Indonesia. "Pemerintah-MUI Sepakat BPJS Kesehatan Direvisi Agar Sesuai Syariah." https://mui.or.id/berita/569/. Diakses tanggal 7 Agustus 2020.

Majelis Ulama Indonesia. "Pemerintah-MUI Sepakat BPJS Kesehatan Direvisi Agar Sesuai Syariah." https://mui.or.id/berita/569/. Diakses tanggal 7 Agustus 2020.

Majelis Ulama Indonesia. "Sejarah MUI." https://mui.or.id/sejarahmui/. Diakses tanggal 7 Agustus 2020.

Mardailis. Metode Penelitian. Jakarta: Bumi Aksara, 2002.

Marzuki, Peter Mahmud. Penelitian Hukum. Jakarta: Kencana, 2010.

Mudzhar, M. Atho. Fatwa-Fatwa Majelis Ulama Indonesia: Sebuah Studi Tentang Pemikiran Hukum Islam di Indonesia 1975-1988. Jakarta: INIS, 1993.

Muhammad, Wildan Imaduddin. "Keberanjakan Fatwa dari Legal Opinion Menjadi Legal Binding: Studi Kasus Fatwa DSN MUI Tentang Perbankan Syariah." Jurisprudensi: Jurnal Ilmu Syariah, Perundangundangan, dan Ekonomi Islam, Vol. 11, No. 2 (November, 2019).

MUI Provinsi Jawa Timur. Pedoman Penyelenggaraan Organisasi Majelis Ulama Indonesia. Surabaya: MUI Jawa Timur, 2013.

Mulyati, Mumung. "Kontribusi MUI Dalam Pengembangan dan Penerapan Hukum Islam Di Indonesia." Al-Mashlabah: Jurnal Hukum dan Pranata Sosial Islam, Vol. 07, No. 01 (Agustus 2019).

Najib, Ainun. "Fatwa Majelis Ulama Indonesia Dalam Perspektif Pembangunan Hukum Responsif." Lisan al-Hal: Jurnal Pengembangan Pemikiran dan Kebudayaan, Vol. 4, No. 2 (Desember, 2012).

Noer, Deliar. The Administration of Islam in Indonesia. New York: Cornell Modern Indonesia Projeck, 1978.

Pedoman Penetapan Fatwa Majelis Ulama Indonesia Nomor: U596/MUI/X/1997.

Qarafi (al), Syihabuddin. Al-Dzakirah. Beirut: Dar al-Gharb al-Islami, 1994.

Qardlawi (al), Yusuf. Al-Fatwa bayn al-Indhibath wa al-Tasayyub. Kairo: Dar al-Shafwah li al-Nashr, 1988.

Risnawan, Wawan. "Peran dan Fungsi Infrastruktur Politik dalam Pembentukan Kebijakan Publik." Dinamika: Jurnal Ilmiah Ilmu Administrasi Negara, Vol. 4, No. 3 (September, 2017). 
Sinaga, Erlina Maria Cristin. "Politik Legislasi Hukum Tidak Tertulis Dalam Pembangunan Hukum Nasional." Jurnal RecbtsVinding, Vol. 8, No. 1 (April 2019).

Soekanto, Soerjono. Penelitian Hukum Normatif. Jakarta: Raja Grafindo Persada, 2012.

Soekanto, Soerjono. Pengantar Penelitian Hukum. Jakarta: UI Press, 2008.

Sugiono. Memahami Penelitian Kualitatif. Bandung: Alfabeta, 2009.

Undang-Undang Nomor 12 Tahun 2011 tentang Pembentukan Peraturan Perundang-Undangan.

Undang-Undang Nomor 21 Tahun 2008 tentang Perbankan Syariah.

Wahid, Marzuki. "Legislasi Syari'at Islam Dalam Negara Pancasila." (Makalah Tidak Diterbitkan -- Disampaikan dalam Kegiatan Tadarus Litapdimas Dirjen Pendis Kemenag RI Seri 7, 14 Mei 2020).

Zamroni, Mohammad. "Peran DSN-MUI Dalam Kegiatan Perbankan Syariah." Tasyri': Jurnal Tarbiyah Syariah Islamiyah, Vol. 25 No. 1 (April 2018). 